\title{
Creating a nutritional traffic light able to help in education for diabetes self-management
}

\author{
Priscila Nogueira Lara*, Marcella Lobato Dias Consoli \\ From 20th Brazilian Diabetes Society Congress \\ Porto Alegre, Brazil. 11-18 November 2015
}

\section{Background}

Diabetes mellitus is a chronic disease that requires ongoing medical care, and education on self-management, in order to avoid acute complications and reduce the risk of chronic complications. Feeding recommendation for people with diabetes is no different from healthy people, being based on adequate intake of carbohydrates, proteins and fats adjusted to metabolic targets, energy needs and individual preferences. Educating and motivating people with diabetes to follow continuously eating plan is a major chronic challenge. Applying diabetes education through educational materials reinforcing the theory of good nutrition in order to facilitate the daily meal plan and food choices can be a strategy to improve adherence to nutritional therapy.

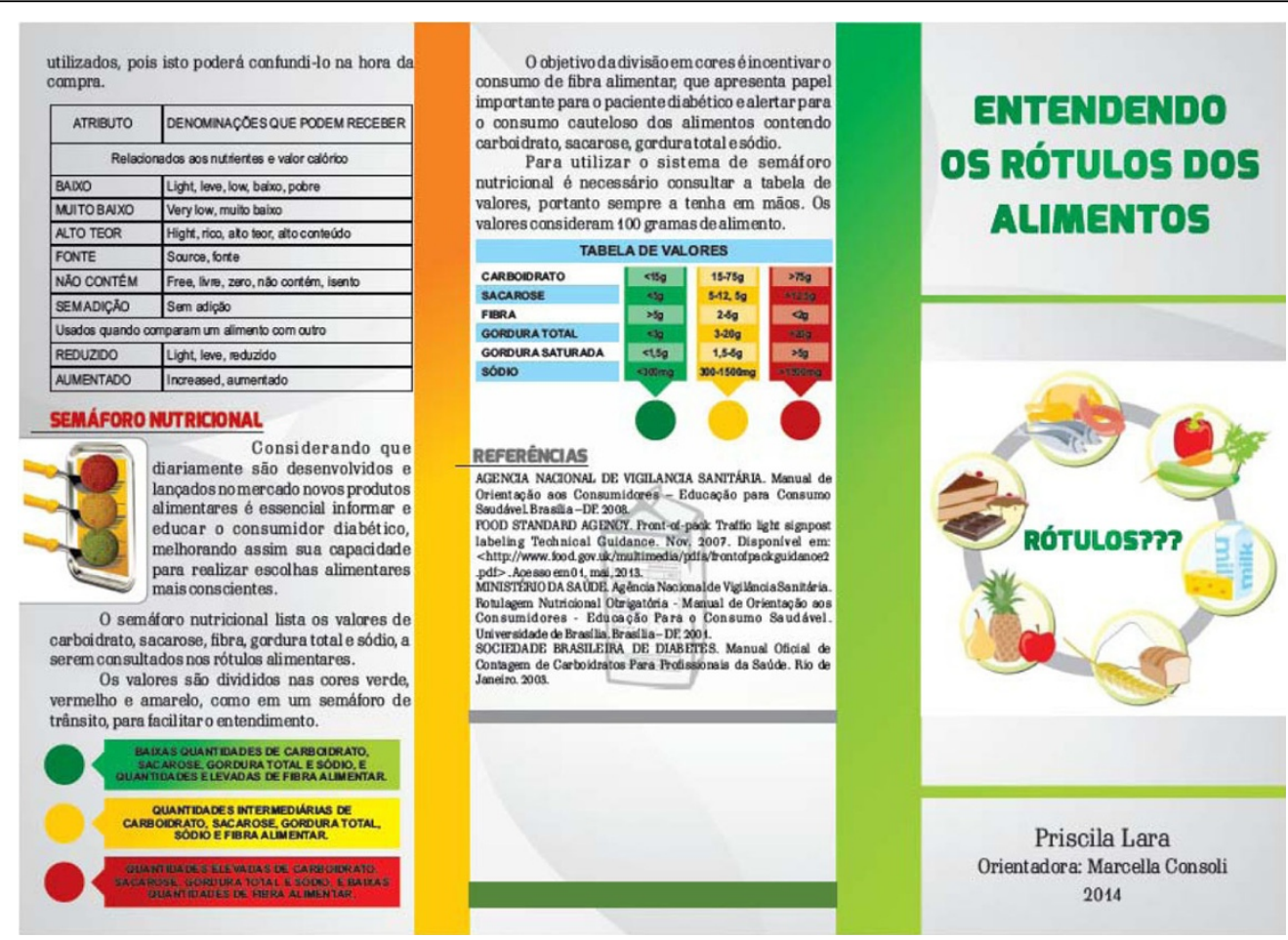

Figure 1 The educational pamphlet.

\footnotetext{
* Correspondence: priscilanlara@yahoo.com.br

Santa Casa Belo Horizonte, Itauna, Brazil
} 


\section{ROTULACEM DE AUMENTOS}

Os rótulos são uma forma de comunicacăo importante entre o consumidor e o produto. Consultar rótulos alimentares é extremamente importante para ficarmos a par do que é oferecido noalimentoqueserá consumido.

No Brasil, a Agência Nacional de Vigilância Sanitária (ANVISA) é o óngăo responsável pela regulação da rotulagem de alimentos que estabelece as informaçóes que um rótulo deve conter.

Bstacartillha traz algumas informacōes par: facilitar as escolhas alimentares da pesson cam diabetes, vis to que existem algumas recomendą̧os nutrioionais que merecem atenção.

As informacoes que devem estar sempre presentes nos rótulos são:

Lista de ingredientes: informa os ingredientes que campöem o produto. Devem estar em ordem decrescente.

- Origem informa quemé of abricante eonde foi fabricado, para que o consumidor saiba a procedência doproduto.

Prazo de validade: devem ser informados pelo menos o dia $e 0 \mathrm{més}$, quando a validade for inferior a três meses; e pelo menos o mês e 0 ano quando o prazo de validade for superior a três meses.

Conteudo liquido: quantidade total de produto contido na embalagem (em quilogramas ou litros).

- Lote: éum número utilizadopara o controle da produçăa. Se houver algum problema com o produto, a referência para que ele seja recolhidoéo lote.

\section{INFORMAČ̃̃O NUTRICIONAL}

A tabela nutricional é um dos itens obrigatórios na rotulagem de um alimento. Ela deve apresentar a porçăo do alimento em gramas ou mililitros, a medida caseira (copo americana, colher de sopa, xdcara...), e o percentual dos valares diários (SVD), que indica em porcentagem o quanto o produto em questăo apresenta de energia e nutrientes com relaçāos uma dieta de $2.000 \mathrm{Kcal}$ Săoitens obrigatórios natabela:

\begin{tabular}{|c|c|c|}
\hline \multicolumn{3}{|c|}{ 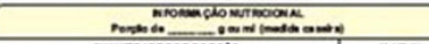 } \\
\hline \multicolumn{2}{|c|}{ 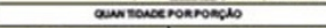 } & sver) \\
\hline Whon beraxinco & $\ldots$ Kast: $\ldots$ & \\
\hline aveacountos & $\cdot$ & \\
\hline mortibus & 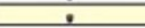 & \\
\hline Domoverus rowe & $\cdot$ & \\
\hline Domonus servenons & $\cdot$ & \\
\hline 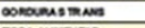 & $\cdot$ & $\dot{-}$ \\
\hline nean Numeriton & $\cdot$ & \\
\hline 80000 & $m$ & \\
\hline
\end{tabular}

- Valor energético: é expresso em forma de calorias, isto é a energia oferecida por determinados nutrientes. Ê expresso em quilocalorias (Kcal) equilojoules (K.J).

Carboidratos: têm função de fornecer energia para o corpo. É o nutriente que mais afeta a glicemia quase $100 \%$ se transforma em glicose (acúcar no sangue) em um intervalo de tempo que varia de 15 minutos a 2 haras. A sacarose é um tipo de carboidrato simples, que tem essa transformacăo muito rápida quando consumida Ê encontrada principalmenteno acúcar demesa.

- Proteinas: săo componentes necessários para a construcăo e manutenção dos nossos brgãos, tecidas e células. Parte da proteína ingerida convertida em glicose, parem em menar quantidade e de forma muitomais lenta que ocarboidrato.

- Garduras totais: săo as principais fontes de energia do nosso corpo e ajudam na absarção das vitaminas $A, D, E$ e K. Podem ser de origem animal ou vegetal. Apenas uma pequena parcela responsável pelo aumento da glicose, e como apresenta uma absarcẫo lenta nāo tem um grande impacto no aumento do acuicarno sangue.
Gorduras saturadas: tipo de gordura presente em alimentos de origem animal. Em grandes quantidades podem aumentar o risco de desenvolver problemas docoracăo.

- Gordura trans: encontrada em grande quantidade em alimentos industrializados, não se deve consumir mais que 2 gramas desta gordura par dia. Também pode aumentar o risco de desenvolver doenças do coração.

- Fibra alimentar: é encontradan os vegetais (follhas, sementes, cascas e eto.). Apesar de ser parte do grupo dos carboidratos, as fibras diminuem sua absorção, já que nāo sẫo digeridas e absorvidas e auxiliam no funcicnamento in testinal.

- Sódio: deve ser consumido com moderacáa, já que em excesso podeelevar a pressão arterial.

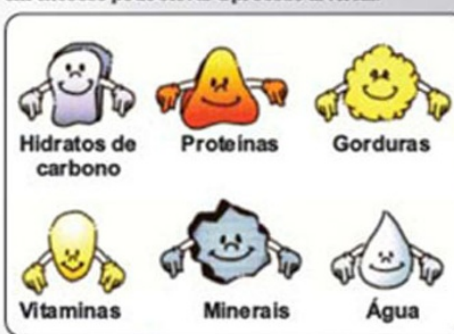

\section{NFORMAČ̃̃O MUTRICIONAL}

COMPLEMENTAR

A informação complementar aparece quando na embalagem do produto se estabelece alguma propriedade nutricional particular, relativa ao seu valor energético ou ao seu conteuda. A comparacão pode ser descritiva quando informar a quantidade de nutrientes e/ou valor energético contido no alimento, ou comparativa quando comparar estes valores com outros produtos ou comomesmoalimento tradicional.

E importante ter atenção aos termos

Figure 2 The educational pamphlet.

\section{Objective}

To develop an educational material with nutritional information on food labeling that is able to assist the population with diabetes to make healthful choices.

\section{Materials and methods}

The educational material was divided into four parts: 1- labeling food; 2- nutritional information; 3- complementary nutritional facts; 4- nutritional traffic light. The traffic light colour approach to nutritional signpost labelling requires criteria that define the green color if key nutrient is less than or equal $5 \%$ of recommendation, amber if between $5 \%$ and $25 \%$ and red if key nutrient is more than 25 . The material was applied to individuals with type 2 diabetes and rated by a specific questionnaire in order to verify its effectiveness.

\section{Results}

The chosen format was an informative pamphlet. The final document is located in Figure 1. The nutritional traffic light was able to make the nutritional labeling simpler and easier for the consumer's understanding.
The use of traffic light colour approach in food labeling has already been tested in other studies that observed changes in the consumer choice behavior. On the evaluation of the effectiveness of the material, the seven specific questions related to the attributes of nutrition labeling, answered by 36 patients who completed the study, a significant increase in the percentage of hits in four of them. This average increase was $42,2 \%$.

\section{Conclusion}

The elaborate educational material was considered satisfactory and fulfilled its role of assisting the food choices of people with diabetes.

Published: 11 November 2015
doi:10.1186/1758-5996-7-S1-A172

Cite this article as: Lara and Consoli: Creating a nutritional traffic light able to help in education for diabetes self-management. Diabetology \& Metabolic Syndrome 2015 7(Suppl 1):A172. 